\title{
Farmer's Resources Uses and Technical Efficiency of Soybean Production in the Shan State of Myanmar
}

\author{
Phyo Thi Thi Swe \\ Agricultural Information Institute (AII), Chinese Academy of Agricultural Sciences \\ Haidian, Beijing.100081, China
}

\begin{abstract}
This study was conducted to investigate the production efficiency and profitability of soybean farmers in the Shan State areas of Myanmar during July and August 2019. Southern Shan state of Taunggyi and northern Shan State of Kyaukme Township was chosen as representative regions under soybean production from where nine villages of Kyaukme and three villages of Taunggyi were selected. A total of 108 farmers took to analyze the data. Gross margin analysis was employed to compare the profitability of soybean by two income groups in each region. Descriptive statistics and Cobb-Douglas stochastic production frontier using FRONTIER 4.1 were applied to analyze the factors affecting the yield of soybean and resource use efficiency. The result reveals that: technical efficiency in two regions, farmers in Kyaukme achieved the mean technical efficiency of 0.49 which is lower than in Taunggyi with the average technical efficiency of 0.83 . In the short run, there is a scope for increasing soybean production by $51 \%$ in Kyaukme and by $17 \%$ for Taunggyi through efficient resource use. Therefore, an improvement in technical efficiency is still possible under present technology in the study areas.
\end{abstract}

Keywords: Soybean production, Technical efficiency, stochastic production function

DOI: $10.7176 / \mathrm{JESD} / 11-16-07$

Publication date:August $31^{\text {st }} 2020$

\section{Introduction}

Myanmar is an agro-based country in which the agriculture sector is the backbone of its economy. It contributes $30 \%$ (2019) of GDP; $25 \%$ of the total export earnings and employs $56 \%$ of the labor force (MOALI, 2019).

Among the State's economic objectives, "development of agriculture sector as a base and all-round development of other sectors of the economy as well", expresses the vital role of agriculture in the State's economic sector. To increase crop production, expansion of area and technology is needed for local consumption and to generate more surpluses of agricultural products for the increase of export earnings.

Soybean (Glycine $\max (\mathrm{L})$. Merr.) is an important global crop because of its nutritive and economic values. It contains approximately $45 \%$ protein and $19 \%$ vegetable oil, $19 \%$ carbohydrates, and has a good balance of amino acids. Nowadays, there is a success story with many uses of soybean not only as food (tofu, soymilk, vegetable oil, etc.) and other household commodities (cosmetics, biofuel, soap, etc.) for human but also as animal feeds (soybean cake) for poultry and aquaculture farming. In Pennsylvania, soybean oil is the most prevalent starting material for bio-diesel (Core, 2005). Moreover, soybean has an expanding role in crop rotation with rice, wheat, etc. either as a grain crop or a green manure crop that is plowed into the ground, returning nitrogen and organic matter to the soil. Also, the introduction of soybean into crop rotation can break the buildup of pests and diseases in cereals. Therefore, soybean has become one of the favorite crops for crop rotation in temperate countries such as the northern People's Republic of China and North and South America (FAO, 1994).

Soybean is the world's foremost provider of valuable protein and oil. Conventionally it has been exploited primarily as a source of edible oil for human food, and protein-rich meal for livestock. Traditional soybean foods have been consumed in oriented countries for centuries, but this accounts for only a small fraction of the world soybean production. Many developing countries (Brazil, Colombia, India, Indonesia, Nigeria, Sri Lanka, Thailand, Zambia, etc.) have recognized the potential of soybean as a source for supplementing the traditional cereal staples with much-needed protein and calories. National level programs are in place in these countries to expand the production potential of soybean. To feed millions of people who face a serious nutritional problem, the promotion of soybean becomes a solution in eliminating malnutrition and poverty in sub-Saharan countries (IITA, 1998).

This article estimates a stochastic production frontier based on a rural household-level panel dataset and tries to identify the sources of technical efficiency in Soybean production. To our knowledge, no other study exists that applies a stochastic production frontier model to household-level data for soybean production sector-1. The paper is organized as following: section-2 reviews studies on technical efficiency of soybean production with a focus on the soybean production; section- 3 goes over literature on technical efficiency and establishes the stochastic production frontier model; section 4 describes the data set and section -5 presents the results. Section- 6 summarizes the conclusions. 


\section{Literature review}

\subsection{Study of technical efficiency in agriculture}

Thanda Kyi and Matthias von Oppen (2001) evaluated the issues of improving the efficiency and productivity of irrigated rice in Myanmar. The empirical results showed that the seed rate used in rice production in the study area was an important variable in increasing total output. To increase the efficiency of the rice farms, upgrading the human resource and extension contact is required for the improvement of rice production. The inefficient use of fertilizer was found for large farmers who use fertilizer.

Theingi Myint (2001) studied the technical efficiency and the profitability of different farm sizes and different yield levels of rice farmers in Pyinmana township. The most important constraints to get the highest yield were the high price of fertilizer, the shortage of irrigated water, the limited capital, the poor technical knowledge on plant protection and the availability of information for obtaining the seeds of high yielding varieties. In cost and return analysis, small farm size group was the most financially attractive enterprise among the different farm size groups. Farmers of medium and large farm size groups achieved higher technical efficiency than that of small farm size groups relative to their respective frontier associated with different levels of technology.

Aye Aye Khin (2002) analyzed the farm-specified technical, allocative, and economic efficiencies of the sample sugarcane farmers in Pyinmana, Tatkone, and Yedashe townships. The application of urea fertilizer, the total labor and draught power used by the farm from land preparation to transporting to the sugar-mill, and the farmers' experience in sugarcane cultivation were the most important explanatory variables in the frontier estimate. All sample farmers were not fully economically efficient in sugarcane production. About $40-70 \%$ of all sample farmers achieved moderate economic efficiency in sugarcane production. Therefore, the results pointed out the encouragement for reaching the optimal allocation of resources in their farms was necessary to improve their income and welfare.

Siregar and Sumaryanto (2003) investigated soybean production efficiency in the irrigated area of the Brantas river basin through a stochastic frontier production function using FRONTIER program version 4.1. The study found that the average level of technical efficiency of soybean production was 0.83 . But about $23 \%$ of soybean farmers had a technical efficiency of less than 0.80 . This implied that there was still an opportunity to improve efficiency if technically inefficient factors could be identified. In this analysis, estimated inefficiency factors such as number of land plots, own irrigated land, cultivated irrigated land, income per capita, age, education, diversification index, number of adult family members and education of adult family members were not significant.

Richetti and Peis (2003) evaluated the economic efficiency of productive resource utilization in the cultivation of soybean in the state of Mato Grosso do Sul, Brazil. The study area comprised the state's main soybean-producing counties. The mean economic efficiency level was $0.8028(80.28 \%)$. This was not a low level but indicated that additional productivity gain and/or production cost reduction may be obtained through more efficient utilization of productive resources. The findings meant that there was a high efficiency in the state, and also partial economic inefficiency in the productive processes of soybean producers who had limited ability to take advantage of available technology and obtain better economic results.

Production efficiency of high-income and low-income pre-monsoon cotton farmers (2002-2003) in Kyaukse and Meikhtila townships was estimated by Tun Win (2004) through technical efficiency measurement to find out factors affecting the production of cotton. Indicating the mean efficiency of pre-monsoon cotton farmers was 0.67 , the result implied that in the short run, there was a scope for increasing cotton production by $33 \%$ by adopting the technology and techniques used by the best practice cotton farms.

\subsection{Improvement of soybean production in Myanmar}

Aung May Than, Kyaw Win, Myint Myint San, and John Ba Maw (2005)identified high yielding soybean varieties with high oil content suitable for specific regions. The experiment was conducted at five research stations - Yezin, Aungban, Kyaukme, Loikaw, Naungmon, and farmers' field at Kalaw Township from 1997 to 2002-2003 using six soybean cultivars introduced from USA and Pacific company (Australia) and local variety Shan Sein as a check. Among seven varieties, GM-95-8, GM-95-9, GM-94-1, and SB-60 gave superior yield over Shan Sein. GM-9118 had the lowest yield. The highest mean yields of all genotypes were found in Kyaukme and Aungban areas where there has a favorable environment for soybean production. GM-95-9 gave the highest yield in those areas and the lowest yield in the Yezin area. GM-95-8 and GM-94-1 with high yield and high stability were suitable for all environments. GM-95-9 with high yield and low stability were suitable for specific environments such as Aungban and Kyaukme. According to the quality analysis of soybean grain, GM-95-8 and GM-94-1 had the highest oil content $24 \%$ and $40-43 \%$ of protein content.

Khin Htay, Myint Lwin, Aung Shwe, and Tin Htut (2002) investigated the effect of different bio-fertilizers on soybean production. Rhizobium peat-inoculants (Myanmar product), Bio-super foliar (Myanmar product), TLB-Tianlibao biofertilizer (Chinese product), EM- Effective Microbes (Japanese product) and Chemical fertilizers (Urea, T-Super, Potash) at the recommended rate were applied for the production of soybean cultivar, SB-60, in four successive crop seasons from February 1995 to June 1996. All the effects of bio-fertilizers and 
chemical fertilizers on Soybean seed yield were better than that of control. Of these bio-fertilizers, EM was the most effective and TLB was the least. Increased yield due to bio-fertilizers was inconsistent. EM was more effective in summer than that of monsoon and winter. The effect of BSF seemed to be more stable than other biofertilizers because it is not a real bio-fertilizer and the plant can consume the chemical nutrients of BSF directly from the leaves. NPK fertilizers were the most effective in the last crop season. It seemed that the cumulative effect of phosphorus may be better one season after another. The study recommended that EM, Rhizobium, and BSF should be used in soybean production. Although their effects were not as good as the effect of NPK fertilizer, they can increase the yield of soybean reasonably and their prices were much lower than NPK fertilizers

\subsection{Theorical framework for resource use efficiency \\ 2.3.1 Production function}

The purpose of research on agricultural production function is to provide a better understanding of input-output relationships and to provide general guides and indications useful to farm managers. Therefore it is necessary to present the classical production function that displays all the characteristics necessary for the study of a production function.

The classical production function can be divided into three regions, each important from the standpoint of efficient resource use. In Figure.1, Region I occurs when the marginal physical product (MPP) is greater than the average physical product (APP). APP is increasing throughout Region I until APP reaches its maximum at the end of Region I. Therefore input use should be continued until Region II is reached.

Region II occurs when MPP is decreasing and is less than APP but greater than zero. The efficiency of the fixed input (e.g. land) is greatest at the end of Region II when the variable input equals "b" units because the number of units of the fixed inputs is constant - usually one. The maximum total output occurs on the upper boundary of Region II.

Region III occurs where MPP is negative. In Region III, further input increment decreases output. The largest amount of variable input that would be used is " $b$ " units. Thus, the area of economic relevance is defined by Region II and its boundaries.

To determine the point of diminishing returns, the elasticity of production (Ep) is measured by the degree of responsiveness between output and input.

\section{$\mathbf{E p}=\mathbf{M P P} / \mathbf{A P P}=\quad \frac{\% \text { change in input }}{\% \text {. }}$}

In Region I, MPP is greater than APP. Therefore Ep is greater than 1. In Region II, MPP is less than APP and Ep is less than one but greater than zero. In Region III, MPP is negative and Ep is negative. If MPP = APP, Ep equals one. This is at the lower boundary of Region II where occurs the maximum efficiency of the variable inputs used with a minimum amount. At the upper boundary of Region II, MPP equals zero and hence Ep also equals zero. Thus the relevant production interval for a variable input is that interval wherein $0 \leq \mathrm{Ep} \leq 1$.

When MPP is increasing, the total output is increasing at an increasing rate. When MPP is decreasing but positive, total output is increasing at a decreasing rate. When MPP is zero, the total output curve attains a maximum level. When MPP is negative, total output decreases.

\section{Productivity and frontier function}

Productivity growth may be achieved through either technological progress or efficiency improvement (Coelli, 1995). Efficiency is a very important factor in productivity growth especially in developing agricultural economics, where resources are scared. Productivity means the output of the product per unit of resource input. It is strongly related to technical efficiency. Farrell (1957) proposed that economic efficiency consists of two components: technical efficiency and allocative (price) efficiency. Technical efficiency refers to the ability of a decision-making unit (e.g. a farm) to produce the maximum attainable level of output at a given set of inputs and technology. A farm is allocatively efficient if it applies the number of inputs that maximize profit, given the production function and prices it faces. A farm is economically efficient if it is both technically and allocatively efficient.

Ali and Chaudhry (1990) illustrated the conceptual framework of the technical, allocative, and economic efficiency in terms of input-output space (Figure 2). The curve $\operatorname{TPP}_{a}$ represents the average function that is usually estimated by using OLS while the curve $\mathrm{TPP}_{\mathrm{m}}$ represents the maximum possible total output as input $\mathrm{X}$ is increased. This is known as the frontier production function. All firms that produce below $\mathrm{TPP}_{\mathrm{m}}$ are technically inefficient because they give less output at a given level of input. The profit maximization criterion suggests that producers will utilize input level at $X_{1}$ (where the marginal value product of $X$ is equal to its price, $P_{x}$ ) and will produce the technically and allocatively efficient output at $\mathrm{Y}_{1}$. The firm which uses $\mathrm{X}_{2}$ and produces $\mathrm{Y}_{2}$ (represented by point C) is technically and allocatively inefficient. On the other hand, the firm which uses $\mathrm{X}_{2}$ and produces $\mathrm{Y}_{3}$ (represented by point B) is technically efficient but allocatively inefficient. 


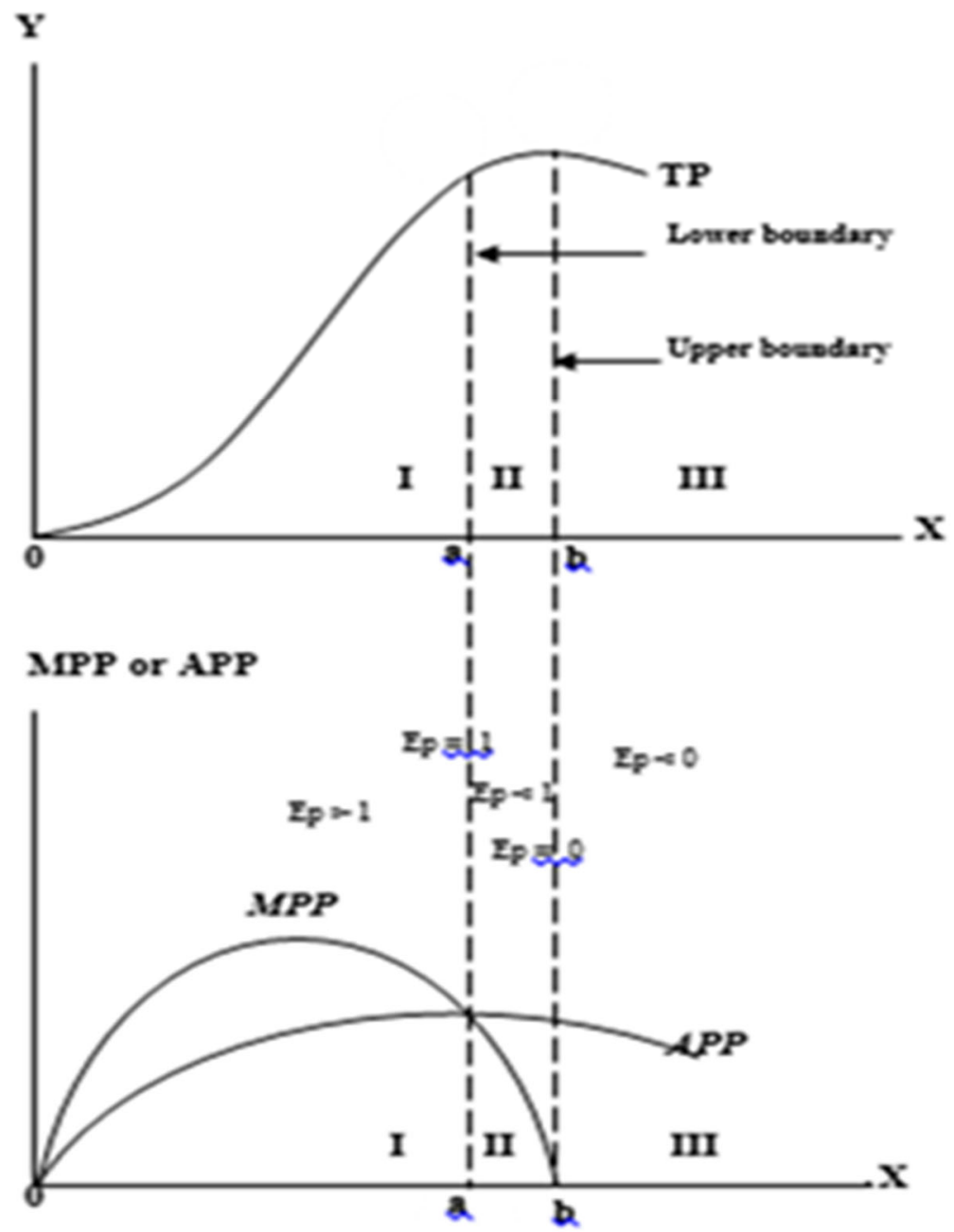

Figure 1. The classical production function, three regions and the elasticity of production

Technical efficiency (TE) is defined as the ratio of a firm's actual output to the technically maximum possible output at a given level of input and can be written as:

\section{$\mathbf{T E}=\mathbf{Y}_{2} / \mathbf{Y}_{3}$}

Allocative efficiency (AE) is expressed as the ratio of the technically maximum possible output at the farmer's level of input to the output obtainable at the optimum level of input that can be written as:

$$
\mathbf{A E}=\mathbf{Y}_{3} / \mathbf{Y}_{1}
$$

Economic efficiency (EE) is the product of technical and allocative efficiencies that can be written as:

$$
\mathbf{E E}=\left(\mathbf{Y}_{2} / \mathbf{Y}_{3}\right)\left(\mathbf{Y}_{3} / \mathbf{Y}_{1}\right)=\mathbf{Y}_{2} / \mathbf{Y}_{1}
$$

Thus the technical, the allocative, and the economic inefficiencies are measured as $\left(1-Y_{2} / Y_{3}\right),\left(1-Y_{3} / Y_{1}\right)$, and $\left(1-\mathrm{Y}_{2} / \mathrm{Y}_{1}\right)$, respectively.

Aigner, Lovell, and Schmidt (1977) and Meeusen and van den Broeck (1977) independently proposed the estimation of a stochastic frontier production function which was defined by:

$$
Y_{i}=f\left(X_{i} ; \beta_{i}\right)+\varepsilon_{i} \quad i=1,2,3, \ldots, N
$$

If $\varepsilon_{\mathrm{i}}$ was a two-sided error term (i.e., if it took both positive and negative values) such that $\varepsilon_{\mathrm{i}} \sim \mathrm{N}\left(0, \sigma_{\varepsilon}{ }^{2}\right)$, then $Y_{i}$ was a stochastic production function. Furthermore, $\varepsilon_{i}$ was half-normally distributed.

where:

In a stochastic frontier, the error term $\left(\varepsilon_{\mathrm{i}}\right)$ is composed of two parts.

$$
\varepsilon_{i}=v_{i}+\mu_{i} \quad i=1,2,3, \ldots, N \text {-.-.-(2) }
$$

$v_{\mathrm{i}}=$ symmetric disturbance, $v_{\mathrm{i}} \sim \mathrm{N}\left(0, \sigma_{v}^{2}\right)$, and represented the stochastic component or random shocks.

$\mu_{\mathrm{i}}=$ one-sided error term derived from a $\mathrm{N}\left(0, \sigma_{\mu}{ }^{2}\right)$ truncated above zero and represented inefficiencies relative to the stochastic frontier.

The two error components, $v_{\mathrm{i}}$ and $\mu_{\mathrm{i}}$, are assumed to be identically and independently distributed so that the variance of $\varepsilon_{\mathrm{i}}$ is equal to the sum of their variances.

A stochastic production frontier model which could be written as:

$$
Y_{i}=f\left(X_{i} ; \beta_{i}\right)+\exp \left(e_{i}\right)
$$


where,

$$
\mathbf{e}_{\mathrm{i}}=\mathbf{v}_{\mathrm{i}}-\boldsymbol{\mu}_{\mathrm{i}}
$$

Therefore, the stochastic frontier variation was due to random effect and inefficiency.

If the frontier production function in equations (3) and (4) is defined for the logarithm of production, then the production of $i^{\text {th }}$ farm is $\exp \left(\mathrm{Y}_{\mathrm{i}}\right)$. Thus the technical efficiency for $\mathrm{i}^{\text {th }}$ farm is measured as:

$\exp$ (Actual output)

$$
\begin{aligned}
& \mathrm{TE}_{\mathrm{i}}=\frac{\exp (\text { Maximum feasible output) }}{\exp \left(\mathrm{X}_{\mathrm{i}} \beta_{\mathrm{i}}+\mathrm{v}_{\mathrm{i}}-\mu_{\mathrm{i}}\right)} \\
& \mathrm{TE}_{\mathrm{i}}=\frac{\left.\operatorname{ex} \mathrm{X}_{\mathrm{i}}+\mathrm{v}_{\mathrm{i}}\right)}{\mathrm{TE}_{\mathrm{i}}}=\exp \left(-\mu_{\mathrm{i}}\right)
\end{aligned}
$$

If $\mu_{\mathrm{i}}=0$, the assumed distribution was half-normal and the farms were 100 percent efficient.

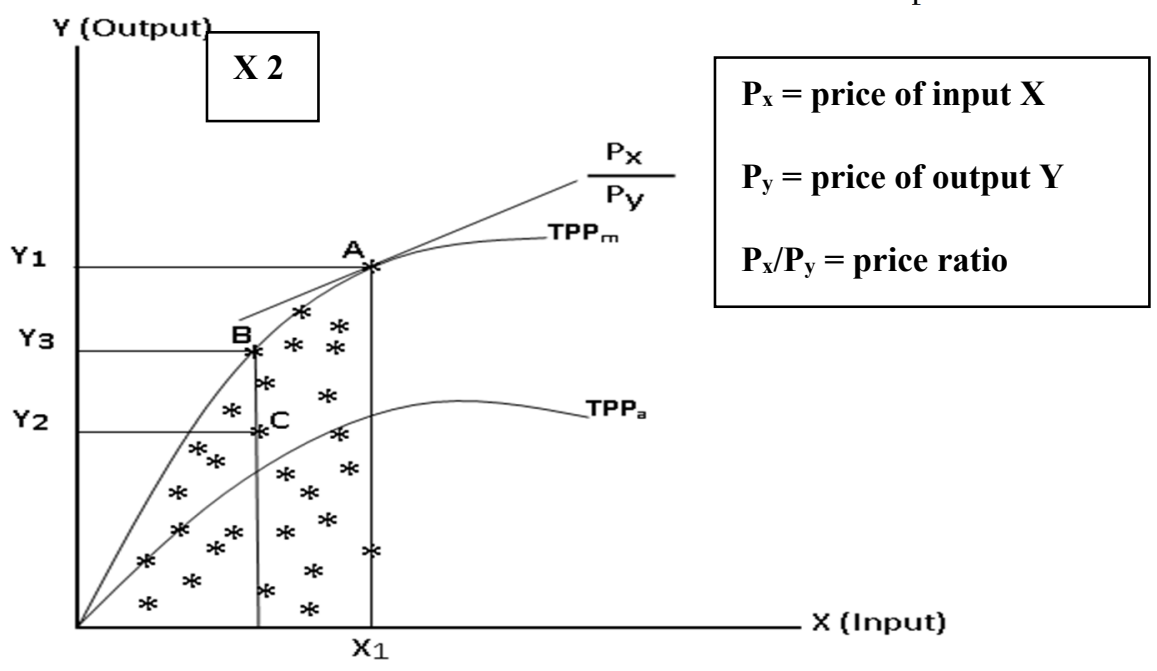

Source: Ali and Chaudhry (1990)

Figure 2. Technical, allocative and economic efficiencies in terms of input-output space

\section{Materials and Methods}

Cross-sectional data were collected from Kyaukme Township in northern Shan State and Taunggyi Township in southern Shan State.

The primary data included the following information: (1) the social characteristics of sample farmers such as age, education level, household's experience in soybean farming, family size, family labor and receipt of extension support from Myanmar Agriculture Service (MAS); (2) farming practices such as land owned, soybean area, varieties used, seed rate per acre, use of fertilizer, pesticide, and manure, labor availability (human and animal labors) and yield obtained; (3) the constraints of soybean production; (4) value of soybean production and family income of sample farmers.

Secondary data were obtained from the Settlement and Land Records Department, Department of Agricultural Planning, Central Statistical Organization, township levels, and other relevant resources.

\subsection{Data Analysis}

Descriptive analysis

To describe and compare the socio-economic profile, yield, input use, existing farming practices, and income of soybean farmers, etc., descriptive analysis was applied.

Gross margin analysis

To evaluate the profitability of soybean production, the concept of gross margin analysis was used. In this analysis, variable costs were taken into account as:
(1) material input cost
(2) hired labor cost
(3) family labor cost as opportunity cost, and
(4) interest on cash cost 
Gross margins are obtained by multiplying the volume of gross output by the farm-gate price received for the product and deducting the variable costs in producing that output. In mathematical form,

Gross Margin $=$ [Volume of gross output $x$ Farm-gate price $]$ - Variable Cost

$=$ Value of Production -Variable Cost

Gross margins are usually expressed on a per-unit basis, i.e., per hectare for crops. While gross margins are a partial measure of the profitability of activities, several parameters are derived from return on capital and labor. These parameters are important for the socio-economic status of the farm household since they indicate the efficiency of resources used in the production process (Blair, 2007). Gross margin analysis can assess not only profitability but also the efficiency of resources utilized. To know the profitability of soybean production by selected townships, the following estimations were computed in gross margin analysis.

(1) Gross margin per unit of land = Value of production - Variable cost

(2) Gross margin per unit of capital = Value of production / Total cash expenses

(3) Gross margin per unit of labor = Gross margin + Human labor cost /Total man-days

\subsection{Model Specification and Measurement of technical efficiency}

To empirically estimate the Cobb-Douglas stochastic frontier production function using FRONTIER 4.1, the study adopted the procedure developed by Aigner et al (1977) which incorporated both stochastic ( $v)$ and technical inefficiency $(\mu)$ disturbance terms.

The stochastic frontier model for soybean farmers in Kyaukme is explained by equation (1) and equation (2).

$$
\operatorname{Ln} Y_{i}=\beta_{0}+\beta_{1} \operatorname{Ln} X_{1}+\beta_{2} \operatorname{LnX} X_{2}+\ldots+\beta_{6} \operatorname{LnX} X_{6}+e_{i}
$$

Ln represents the natural logarithm, $\mathrm{i}$ refers the $\mathrm{i}^{\text {th }}$ farm in the sample, $\mathrm{Y}$ Yield of soybean (basket/ac), $\mathrm{X}_{1}$ Seed rate used (pyi/ac),X2 Human labor used (man day/ac),X3 Application of bio-super foliar provided by OPEC project as dummy ( $1=$ use, $0=$ no use),X4 Farm size (acre),X5 Annual incomes (kyat/year),X6 Animal labor applied (animal day/ac), $\beta_{0} \quad$ Constant, $\beta_{\mathrm{i}} \quad$ Estimated coefficients, $\mathrm{i}=1,2,3, \ldots$

etc... $\mathrm{e}_{\mathrm{i}}=v_{\mathrm{i}}-\mu_{\mathrm{i}}\left(\mu_{\mathrm{i}} \geq 0\right), v_{\mathrm{i}} \quad$ are assumed to be independent and identically distributed random errors, having , $\mathrm{N}\left(0, \sigma^{2}\right)$ distribution, independent of the $\mu_{\mathrm{i}}$

$\mu_{\mathrm{i}}$ are technical inefficiency effects, which are assumed to be non-negative random variables independently and identically distributed such that $\mu_{\mathrm{i}}$ is defined by the truncation at zero of the $\mathrm{N}\left(0, \sigma^{2}\right)$ distribution

$\boldsymbol{\mu}_{\mathrm{i}}=\boldsymbol{\delta}_{\mathbf{0}}+\boldsymbol{\delta}_{\mathbf{1}} \mathbf{Z}_{\mathbf{1}}+\boldsymbol{\delta}_{\mathbf{2}} \mathbf{Z}_{\mathbf{2}}+\boldsymbol{\delta}_{\mathbf{3}} \mathbf{Z}_{\mathbf{3}}+\boldsymbol{\delta}_{\mathbf{4}} \mathbf{Z}_{\mathbf{4}}$

The error term formula shown as $\mu_{\mathrm{i}}$ are technical inefficiency effect predicted by the model itself, $\delta_{0}$ Constant, $\delta_{\mathrm{i}} \quad$ are parameters to be estimated, $Z_{1}$ Household's experience in soybean farming (year), $\mathrm{Z}_{2} \quad$ Education level as a dummy $(1=$ middle and above, $0=$ otherwise $), Z_{3}$ Age of a farmer (year), $Z_{4}$ Extension service received (yes $=1$, no $=0$ ).

The stochastic frontier model for soybean farmers in Taunggyi is explained by equation (3), but the technical inefficiency effect is explained by the same equation as in Kyaukme.

$\operatorname{Ln} \mathbf{Y} i=\beta_{0}+\beta_{1} \operatorname{Ln} X_{1}+\beta_{2} \operatorname{Ln} X_{2}+\beta_{3} \operatorname{Ln} X_{3}+\beta_{4} \operatorname{Ln} X_{4}+e_{i}$

$\mathrm{Ln} \quad$ represents the natural logarithm, $\mathrm{i}$ refers the $\mathrm{i}^{\text {th }}$ farm in the sample, $\mathrm{Y}$ Yield of soybean (basket/ac), $\mathrm{X}_{1}$ Seed rate used (pyi/ac), $X_{2}$ Human labor used (man-day/ac), $X_{3} \quad$ Farm $\quad$ size $\quad$ (acre), $X_{4}$ Annual incomes (kyat/year), $\beta_{0} \quad$ Constant, $\beta_{i} \quad$ Estimated coefficients: $i=1,2,3, \ldots$. etc., $e_{i}=v_{i}-$ $\mu_{\mathrm{i}}\left(\mu_{\mathrm{i}} \geq 0\right), \nu_{\mathrm{i}} \quad$ are assumed to be independent and identically distributed random errors, having $\mathrm{N}\left(0, \sigma^{2}\right)$ distribution, independent of the $\mu_{\mathrm{i},}, \mu_{\mathrm{i}} \quad$ are technical inefficiency effects, which are assumed to be nonnegative random variables independently and identically distributed such that $\mu_{\mathrm{i}}$ is defined by the truncation at zero of the $\mathrm{N}\left(0, \sigma^{2}\right)$ distribution.

To measure the farm-specific technical inefficiency $\left(\mathrm{TE}_{\mathrm{i}}\right)$, the above model was estimated using FRONTIER 4.1. The maximum likelihood estimates of the parameters of the frontier model are estimated, such that the variance parameters are expressed in terms of the parameterization:

$$
\begin{gathered}
\sigma_{s}^{2}=\sigma_{v}^{2}+\sigma_{\mu}^{2} \\
\gamma=\sigma^{2} / \sigma_{s}^{2}
\end{gathered}
$$

Where $\gamma$-parameter has a value between zero and one.

Battese and Coelli (1995) stated that the technical efficiency of production of the $i^{\text {th }}$ farm is estimated as:

$\mathrm{TE}_{\mathrm{i}} \quad=\exp \left(\mathrm{X}_{\mathrm{i}} \beta+v_{\mathrm{i}}-\mu_{\mathrm{i}}\right) / \exp \left(\mathrm{X}_{\mathrm{i}} \beta+v_{\mathrm{i}}\right)$

$$
\mathrm{TE}_{\mathrm{i}} \quad=\exp \left(-\mu_{\mathrm{i}}\right)
$$

If $\mu_{\mathrm{i}}=0$, the farms were $100 \%$ efficient.

\section{Result and Discussion}

The result of this paper was shown as farmers are profitable from soybean production in study areas, farmers are 
technically inefficient in soybean production in Myanmar, socio-economic characteristics of farmers, and institutional factors do reflect the farm-specific resource use inefficiency.

\subsection{Demographic characteristics of the sample farmers in the study areas}

The demographic characters of the selected farmers categorized by annual family income are presented in Table 5.1 .

In Kyaukme township, the age of low-income farmers was a mean value of 49 years old. For high-income farmers, it was an average of 45 years old. The mean age of all sample farmers was 47 years old.

In Taunggyi Township, the age of low-income farmers and high-income farmers was 37 and 38 years respectively. As a whole, the mean age was about 38 years old. Here, the age of the selected farmers represents only the age of the respondents who came and answered the questionnaire. Therefore it does not represent the age of the household head.

The family size of two-income groups and all sample farmers in Kyaukme was the same as the mean number of 5. In Taunggyi, low-income farmers had a family size of 6 and high-income farmers, and all sample farmers had a family size of 5 .

Family labor in farming for both townships and all income groups was the same mean number of 3 . Ages of all family labors in both townships were mostly between 18 and 60 years.

Household's experience in soybean farming in Kyaukme was mean values of 20 years for low-income farmers, 16 years for high-income farmers, and 18 years for all farmers. In Taunggyi, the low-income group had a mean value of 12 years of household's experience in soybean farming while the high-income group had 40 years of household's experience. For all sample farmers, it was 14.7 years of household's experience.

About $88 \%$ of farmers in Kyaukme obtained primary education and only $12 \%$ of farmers attained secondary education. In Tauggyi, $66 \%$ of farmers obtained primary education and only $34 \%$ had secondary education.

Table 5.1 Demographic characteristics of the sample farmers in the study areas

\begin{tabular}{|c|c|c|c|c|c|c|c|c|}
\hline \multirow[b]{2}{*}{ No. } & \multirow[b]{2}{*}{ Item } & \multirow[b]{2}{*}{ Unit } & \multicolumn{3}{|c|}{ Kyaukme $(n=76)$} & \multicolumn{3}{|c|}{ Taunggyi ( $n=32$ ) } \\
\hline & & & $\begin{array}{l}\text { Low- } \\
\text { income } \\
\text { group }\end{array}$ & $\begin{array}{l}\text { High- } \\
\text { income } \\
\text { group }\end{array}$ & All & $\begin{array}{l}\text { Low- } \\
\text { income } \\
\text { group }\end{array}$ & $\begin{array}{l}\text { High- } \\
\text { income } \\
\text { group }\end{array}$ & All \\
\hline 1. & Age & year & $\begin{array}{c}49 \\
(10.5)\end{array}$ & $\begin{array}{c}45 \\
(11.1)\end{array}$ & $\begin{array}{c}47 \\
(11)\end{array}$ & $\begin{array}{c}37 \\
(19)\end{array}$ & $\begin{array}{c}38 \\
(13)\end{array}$ & $\begin{array}{c}38 \\
(13)\end{array}$ \\
\hline 2. & Family size & no. & $\begin{array}{c}5 \\
(1.7)\end{array}$ & $\begin{array}{c}5 \\
(1.7)\end{array}$ & $\begin{array}{c}5 \\
(3)\end{array}$ & $\begin{array}{c}6 \\
(3)\end{array}$ & $\begin{array}{c}5 \\
(1)\end{array}$ & $\begin{array}{c}5 \\
(1)\end{array}$ \\
\hline 3 & Labor availability & & & & & & & \\
\hline & -under 18 yrs & no. & $\begin{array}{c}2 \\
(1)\end{array}$ & $\begin{array}{c}2 \\
(0.7)\end{array}$ & $\begin{array}{c}2 \\
(1)\end{array}$ & $\begin{array}{c}2 \\
(1.5)\end{array}$ & $\begin{array}{c}2 \\
(0.7)\end{array}$ & $\begin{array}{c}2 \\
(0.8)\end{array}$ \\
\hline & $\begin{array}{l}\text {-between } 18 \text { and } \\
60 \text { yrs }\end{array}$ & no. & $\begin{array}{c}4 \\
(1.3)\end{array}$ & $\begin{array}{c}3 \\
(1.4)\end{array}$ & $\begin{array}{c}4 \\
(1.3)\end{array}$ & $\begin{array}{l}3 \\
(1)\end{array}$ & $\begin{array}{c}3 \\
(1)\end{array}$ & $\begin{array}{c}3 \\
(1)\end{array}$ \\
\hline & -over 60 yrs & no. & $\begin{array}{c}1 \\
(0.3)\end{array}$ & $\begin{array}{c}1 \\
(0.7)\end{array}$ & $\begin{array}{c}1 \\
(0.5)\end{array}$ & $\begin{array}{l}3 \\
(-)\end{array}$ & $\begin{array}{c}2 \\
(0.5)\end{array}$ & $\begin{array}{c}2 \\
(0.9)\end{array}$ \\
\hline 4. & $\begin{array}{l}\text { Family labor in } \\
\text { farming }\end{array}$ & no. & $\begin{array}{c}3 \\
(1)\end{array}$ & $\begin{array}{c}3 \\
(1.3)\end{array}$ & $\begin{array}{c}3 \\
(1.2)\end{array}$ & $\begin{array}{c}3 \\
(0.8)\end{array}$ & $\begin{array}{c}3 \\
(0.9)\end{array}$ & $\begin{array}{c}3 \\
(0.9)\end{array}$ \\
\hline 5. & $\begin{array}{l}\text { Household's } \\
\text { experience }\end{array}$ & year & $\begin{array}{c}20 \\
(12)\end{array}$ & $\begin{array}{l}16 \\
(9)\end{array}$ & $\begin{array}{c}18 \\
(11)\end{array}$ & $\begin{array}{c}12 \\
(10.5)\end{array}$ & $\begin{array}{c}40 \\
(10)\end{array}$ & $\begin{array}{l}14.7 \\
(10)\end{array}$ \\
\hline 6. & Education level & dummy & $\begin{array}{l}0.0857 \\
(0.28)\end{array}$ & $\begin{array}{c}0.15 \\
(0.36)\end{array}$ & $\begin{array}{l}0.12 \\
(0.3)\end{array}$ & $\begin{array}{l}0.25 \\
(0.5)\end{array}$ & $\begin{array}{c}0.36 \\
(0.49)\end{array}$ & $\begin{array}{c}0.34 \\
(0.48)\end{array}$ \\
\hline & -primary $(0)$ & $\%$ & 91.43 & 85.36 & 88 & 75 & 64.29 & 65.62 \\
\hline & -secondary (1) & $\%$ & 8.57 & 14.43 & 12 & 25 & 35.71 & 34.38 \\
\hline
\end{tabular}

Figures in parentheses represent standard deviation. All are mean values

\subsection{Gross margin analysis}

The results of gross margin analysis were explained in Table 5.2 for the Taunggyi township and in Table 5.3 for the Kyaukme township to evaluate profitability and efficiency of resource use in soybean production. All figures were shown as mean values. Material inputs costs were calculated with effective price or field price of all inputs in soybean production. Farm-gate price was used as the price of output. Total labor costs were counted total human labor in man day of all farming practices into market wage rates. Total labor items included both family and hired laborers.

In Taunggyi, the value of production for low-income farmers was slightly higher (116,250 kyats) than that for high-income farmers $(109,155$ kyats). Gross margins of the low-income group were higher than those of the high-income group. This was because total variable cost, total cash expenses, and total labor cost for the former 
group were low compared to those for the latter group. Therefore gross margin per unit of land was higher $(65,250$ kyats per acre) in the low-income group while that was lower $(52,454$ kyats per acre) in the high-income group. This indicates that resources were more efficiently used in the low-income farmers for soybean cultivation. The gross margin per unit of capital was 4.95 kyats in low-income farmers while it was 3.63 kyats in high-income farmers. This means that the former income group would earn more than the latter group if they invested a unit cash expense. As for gross margin per unit of labor, the low-income farmers would pay 2,572 kyats per man-day in soybean cultivation whereas the high-income farmers would give the wage of 2,245 kyats. This explains that low-income farmers would support more wages for labor used in soybean cultivation if they obtained more return from the sale of soybean. Therefore it can be said that farmers of the high-income group utilized their resources more efficiently.

In Kyaukme, the value of production for low-income farmers was inverse compared with that in Taunggyi, i.e., lower in a low-income group than in the high-income group. Gross margin per unit of land was 19,993 kyats per acre in low-income farmers while it was 28,324 kyats in high-income farmers. This was because the former group did not utilize resources such as chemical fertilizers in soybean cultivation as much as the latter applied. Gross margins per unit of capital were the same in both income groups, i.e., they would earn about 2 kyats if they invested a unit cash expense. Gross margin per unit of labor for low-income farmers was 1,946 kyats per man-day while it was 2,232 kyats in high income. The latter would pay more wages per man-day than the former if they got more return from the sale of soybean. In general, farmers of the low-income group in Kyaukme utilized fewer inputs in soybean cultivation compared to farmers of high-income groups. Therefore, they had attained low-profit margins in soybean production rather than farmers of the high-income group.

Comparing the gross margin analysis of two regions, farmers in Taunggyi earned more than farmers in Kyaukme.

Table 5.2 Gross margin analysis for soybean cultivation of farmers in Taunggyi township

\begin{tabular}{|c|c|c|c|c|c|}
\hline \multirow{2}{*}{ No. } & \multirow{2}{*}{ Item } & \multirow{2}{*}{ Unit } & \multicolumn{2}{|c|}{ Income Group } & \multirow{2}{*}{ All } \\
\hline & & & Low & High & \\
\hline 1 & Value of production & kyat/ac & 116,250 & 109,155 & 110,042 \\
\hline 2 & Total variable cost & kyat/ac & 51,000 & 56,701 & 55,988 \\
\hline 3 & Total cash expenses & kyat/ac & 23,500 & 30,099 & 29,274 \\
\hline 4 & Total labor cost & kyat/ac & 41,500 & 41,878 & 41,831 \\
\hline 5 & Total labor & man day/ac & 41.5 & 42 & 42 \\
\hline 6 & Gross margin per unit of land & kyat/ac & 65,250 & 52,454 & 54,054 \\
\hline 7 & Gross margin per unit of capital & kyat/unit cost & 4.95 & 3.63 & 3.76 \\
\hline 8 & Gross margin per unit of labor & kyat/man day & 2,572 & 2,245 & 2,286 \\
\hline
\end{tabular}

Table 5.3 gross Margin Analysis for soybean cultivation of farmers in Kyaukme Township

\begin{tabular}{|c|c|c|c|c|c|}
\hline \multirow{2}{*}{ No. } & \multirow{2}{*}{ Item } & \multirow{2}{*}{ Unit } & \multicolumn{2}{|c|}{ Income Group } & \multirow{2}{*}{ All } \\
\hline & & & Low & High & \\
\hline 1 & Value of production & kyat/ac & 115,969 & 142,900 & 130,498 \\
\hline 2 & Total variable cost & kyat/ac & 95,976 & 114,576 & 106,010 \\
\hline 3 & Total cash expenses & kyat/ac & 56,868 & 75537 & 66,940 \\
\hline 4 & Total labor cost & kyat/ac & 63,506 & 63,899 & 63,718 \\
\hline 5 & Total labor & man day/ac & 43 & 41 & 42 \\
\hline 6 & Gross margin per unit of land & kyat/ac & 19,993 & 28,324 & 24,487 \\
\hline 7 & Gross margin per unit of capital & kyat/unit cost & 2.04 & 1.89 & 1.95 \\
\hline 8 & Gross margin per unit of labor & kyat/man day & 1,946 & 2,232 & 2,097 \\
\hline
\end{tabular}

5.3 Summary statistics of the variables for sample soybean farmers in Taunggyi township

The detailed summaries of the variables involved in the frontier production function of the sample soybean farmers in Taunggyi township are described in Table 5.4.

Based on the survey data, the mean yield of soybean for the low-income group was 17.5 baskets per acre with a range of 5 to 25 baskets per acre. For the high-income group, the average yield was 14.2 baskets per acre ranging from 5 to 35 baskets per acre. For all farmers, the mean yield was 14.6 baskets per acre with a range of 5 to 35 baskets per acre.

All farmers in the low-income group applied the average amount of seed rate 8 pyis per acre in soybean production. For high-income farmers and all farmers, the average seed rates were 11 pyis and 10.6 pyis per acre respectively, ranging from 4 to 32 pyis per acre. 
The average human labor used in soybean farming including hired and family labor was noted to be the same man-days of 42 per acre in both income groups, but 41 man-days per acre were found for all farmers.

The average farm size was 2.75 acres for both income groups. The range was 1 to 4 acres in the low-income group while it was found to be 0.5 to 6 acres for the high-income group.

The low-income farmers earned an average annual income of 119,250 kyats with a range of 35,000 kyats to 228,000 kyats while the high-income farmers obtained an average annual income of 1,726,479 kyats ranging from 566,000 kyats to 5,354,000 kyats.

The household's experience in soybean farming was a mean value of 12 years ranging from 2 to 22 years for the low-income group while it was 15 years ranging from 3 to 40 years for the high-income group. For all farmers, it was 14.7 years ranging from 2 to 40 years.

The average level of education of soybean farmers was not so much different for both income groups. Only $25 \%$ of low-income farmers and $36 \%$ of high-income farmers possessed secondary education. Only $75 \%$ and $64 \%$ respectively obtained primary education levels in low and high-income groups. As a whole $66 \%$ possessed primary education level. It was found that there was no high educated person in the study area.

The mean age of sample farmers for both income groups was nearly the same as 37 and 38 years old ranging from about 20 to 60 years old.

Low-income farmers did not respond about the receipt of the extension service from MAS. For the highincome group, $21 \%$ of sample farmers received extension contact from MAS. As for all farmers, only $19 \%$ received extension service.

Table 5.4 Summary statistics of the variables for sample soybean farmers in Taunggyi a township

\begin{tabular}{|c|c|c|c|c|c|c|c|c|c|c|}
\hline \multirow{2}{*}{ Variables } & \multirow{2}{*}{ Unit } & \multicolumn{3}{|c|}{ Low-income group } & \multicolumn{3}{|c|}{ High-income group } & \multicolumn{3}{|c|}{ All farmers } \\
\hline & & Mean & Max. & Min. & Mean & Max. & Min. & Mean & Max. & Min. \\
\hline Dependent variable & & & & & & & & & & \\
\hline $\begin{array}{l}\text { Yield } \\
\text { Independent variables }\end{array}$ & basket/ac & 17.5 & 25 & 5 & 14.2 & 35 & 5 & 14.6 & 35 & 5 \\
\hline Seed rate & pyi/ac & 8 & 8 & 8 & 11 & 32 & 4 & 10.6 & 32 & 4 \\
\hline Human labor used & $\begin{array}{l}\text { man } \\
\text { day/ac }\end{array}$ & 42 & 57 & 17 & 42 & 107 & 7 & 41 & 107 & 7 \\
\hline Farm size & acre & 2.75 & 4 & 1 & 2.75 & 6 & 0.35 & 2.33 & 6 & 0.5 \\
\hline Annual income & kyat/year & 119,250 & 228,000 & 35,000 & $1,726,479$ & $5,354,000$ & 566,000 & $1,524,000$ & $5,354,000$ & 35,000 \\
\hline Variables & & & & & & & & & & \\
\hline inefficiency effect & & & & & & & & & & \\
\hline$\overline{\text { Household'sexperience }}$ & year & 12 & 22 & 2 & 15 & 40 & 3 & 14.7 & 40 & 2 \\
\hline Education level & dummy & 0.25 & 1 & 0 & 0.36 & 1 & 0 & 0.34 & 1 & 0 \\
\hline Age of farmer & year & 37 & 61 & 20 & 38 & 65 & 21 & 38 & 65 & 20 \\
\hline Extension contact & dummy & - & - & - & 0.21 & 1 & 0 & 0.19 & 1 & 0 \\
\hline
\end{tabular}

a $n=32$

\subsection{Summary statistics of the variables for sample soybean farmers in Kyaukme township}

Table 5.5 reveals the summary statistics of the variables for sample soybean farmers in Kyaukme township. The mean yield of soybean for the low-income group was 15.9 baskets per acre with a range of 3 to 30 baskets. For the high-income group, it was 18.5 baskets per acre ranging from 5 to 39.6 baskets. As a whole, the average yield of soybean was 17.3 baskets ranging from 3 to 39.6 baskets.

The average seed rate used in soybean cultivation for the low-income group was 14.5 pyis per acre with a range of 8 to 25 pyis. High-income group and all farmers utilized the seed at the average rates of 13.4 and 13.7 baskets per acre respectively, ranging from 4 to 24 pyis.

The human labor used by the low-income group was the mean of 45 man-days ranging from 14 to 94 mandays while for high-income farmers it was 44 man-days with a range of 6 to 111 man-days. For all sample farmers, the average human labor was 44 man-days ranged from 6 to 112 man-days.

Bio-super foliar was applied by $31 \%$ of low-income farmers and by $32 \%$ each of high income and all sample farmers.

The average farm size of the low-income group was 4 acres with a range of 1 to 8 acres while it was 4.9 acres ranging from 1.5 to 13 acres for the high-income group. For all sample farmers, it was 4.3 acres with a range of 1 to 13 acres.

The low-income farmers obtained an average annual income of 221,693 kyats while the high-income farmers earned an average annual income of 5,390,000 kyats. As a whole, the mean value of annual income was 766,510 kyats.

Animal labor with a mean of 4.2 animal days was used by the low-income group while it was a mean of 3.8 animal days applied by the high-income group. As a whole, the sample farmers utilized animal labor with an average of 4 animal days ranging from 1 to 8 animal days per acre in land preparation.

The household's experience in soybean farming was a mean value of 20 years for the low-income group, 15.9 years for the high-income group, and 17.8 years for all farmers.

Only $8.75 \%$ of low-income farmers possessed secondary education level while $15 \%$ of the high-income group 
and $12 \%$ of all farmers obtained secondary education.

The mean age of low and high-income groups and all farmers were not much different, i.e., 49,45 , and 46.9 years old respectively. About $40 \%$ of the low-income group received extension service while about $39 \%$ each of high-income groups and all farmers received extension contact.

Table 5.5 Summary statistics of the variables for sample soybean farmers in Kyaukme ${ }^{b}$ township

\begin{tabular}{|c|c|c|c|c|c|c|c|c|c|c|}
\hline \multirow{2}{*}{ Variables } & \multirow{2}{*}{ Unit } & \multicolumn{3}{|c|}{ Low-income group } & \multicolumn{3}{|c|}{ High-income group } & \multicolumn{3}{|c|}{ All farmers } \\
\hline & & Mean & Max. & Min. & Mean & Max. & Min. & Mean & Max. & Min. \\
\hline Dependent & & & & & & & & & & \\
\hline $\begin{array}{l}\frac{\text { variable }}{\text { Yield }} \\
\text { Independent } \\
\text { variables }\end{array}$ & basket/ac & 15.9 & 30 & 3 & 18.5 & 39.6 & 5 & 17.3 & 39.6 & 3 \\
\hline$\overline{\text { Seed rate }}$ & pyi/ac & 14.5 & 24 & 8 & 13.4 & 24 & 4 & 13.7 & 24 & 4 \\
\hline $\begin{array}{l}\text { Human labor } \\
\text { used }\end{array}$ & $\begin{array}{l}\text { man- } \\
\text { day/ac }\end{array}$ & 45 & 94 & 14 & 44 & 111 & 6 & 44 & 112 & 6 \\
\hline $\begin{array}{l}\text { Bio-super foliar } \\
\text { application }\end{array}$ & dummy & 0.31 & 1 & 0 & 0.32 & 1 & 0 & 0.32 & 1 & 0 \\
\hline Farm size & acre & $\begin{array}{c}4 \\
221603\end{array}$ & $\begin{array}{c}8 \\
309000\end{array}$ & $\begin{array}{c}1 \\
50400\end{array}$ & $\begin{array}{c}4.9 \\
1231508\end{array}$ & 13 & $\begin{array}{c}1.5 \\
413010\end{array}$ & $\begin{array}{c}4.3 \\
766510\end{array}$ & $\begin{array}{c}13 \\
5300000\end{array}$ & $\begin{array}{c}1 \\
50400\end{array}$ \\
\hline Annual income & kyat/year & 221,693 & 399,000 & 59,400 & $1,231,598$ & $5,390,000$ & & & $5,390,000$ & 59,400 \\
\hline $\begin{array}{l}\text { Anımal labor } \\
\text { used } \\
\text { Variables for } \\
\text { inefficiency } \\
\text { effect }\end{array}$ & $\begin{array}{l}\text { anımal } \\
\text { day/ac }\end{array}$ & 4.2 & 8 & 2.7 & 3.8 & 7 & 1 & 4 & 8 & 1 \\
\hline $\begin{array}{l}\text { Household's } \\
\text { experience }\end{array}$ & year & 20 & 50 & 1.17 & 15.9 & 33 & 1.5 & 17.8 & 50 & 1.17 \\
\hline Education level & dummy & 0.0875 & 1 & 0 & 0.15 & 1 & 0 & 0.12 & 1 & 0 \\
\hline Age of farmer & year & 49 & 69 & 25 & 45 & 63 & 17 & 46.9 & 69 & 17 \\
\hline Extension contact & dummy & 0.40 & 1 & 0 & 0.3902 & 1 & 0 & 0.3947 & 1 & 0 \\
\hline
\end{tabular}

$\mathbf{b}_{\mathrm{n}}=76$

\subsection{Parameters of ordinary least square (OLS) and maximum likelihood estimate (MLE) in stochastic frontier production function for sample soybean farmers}

Parameters of ordinary least squares (OLS) and maximum likelihood estimates (MLE) in stochastic frontier production function for sample soybean farmers were estimated using the FRONTIER 4.1 (Coelli, 1996). The normally distributed random error $\left(v_{\mathrm{i}}\right)$ and the half-normal error term $\left(\mu_{\mathrm{i}}\right)$ associated with technical inefficiency were included in this function.

For all sample farmers, the F-value for OLS was 4.030 and it was statistically significant at $\alpha=0.01$. The $\mathrm{R}^{2}$ value of 0.259 indicated that $25.9 \%$ of the variation in yield of soybean was explained by the independent variables in the frontier model. The value of the likelihood ratio test of the one-sided error was 4.34 and it was not significant.

The estimate of the variance $\left(\sigma_{s}^{2}=\sigma_{v}^{2}+\sigma_{\mu}^{2}\right)$ was 0.205 which was highly significant at $\alpha=0.01$. It can be interpreted that significant variation in soybean production was caused by both technical inefficiency and random shocks. The value of $\gamma$ was 0.99 and there was a high significance at $\alpha=0.01$ implying that $99 \%$ of the total variation in farm output was due to technical inefficiency.

\subsection{Determinants of output in the stochastic frontier model of the soybean farmers in Kyaukme township}

The ordinary least square (OLS) and maximum likelihood estimate (MLE) for the parameters of the Cobb-Douglas model defined by equation (1) and (2) were presented in Table 5.6 for Kyaukme township. The determinants of output included in the stochastic frontier model were mentioned as the input variables in the previous section of this chapter.

The function was separately estimated for two-income groups and two townships. The coefficients of the input variables in the production function were elasticities of the mean output concerning the different inputs for the Cobb-Douglas model defined by equation (1) and (2).

Results of the estimation of the frontier productions, OLS and MLE, for all sample farmers in Kyaukme township were described in Table 5.6. The empirical results indicated that the elasticity of frontier (best practice) production concerning human labor was estimated to be negatively related to yield of soybean and they were statistically significant at a $1 \%$ level in both OLS and MLE estimation. Therefore, the inefficient use of human labor was observed in soybean production.

The estimated coefficient for farm size also showed a negative relationship with the yield of soybean and it was significant at a $1 \%$ level in both OLS and MLE. This indicated that larger farms did not reach the scale of economies. The coefficient of bio-super foliar application as a dummy in OLS was positively influenced on yield though not significant in OLS. However, it was negatively significant at a $1 \%$ level in MLE estimation. This pointed out the inefficient and ineffective use of bio-super foliar in soybean production.

The estimates of annual income expressed positive significance at $1 \%$ level. This implied that farmers who 
earned more annual income were efficient in the production of soybean. The positive coefficients of seed rate and animal labor were not significant on the yield of soybean. The small magnitudes of these coefficients showed that the use of seed rate and animal labor can be increased for the yield of soybean.

For the inefficiency model, the negative coefficient of household's experience in soybean farming indicated that well-experienced farmers were more efficient in production. The negative sign of the coefficient of education level as dummy showed the higher the education of farmers, the more efficient in soybean production. The estimated coefficient for the age of the farmer expressed a negative influence on the yield of soybean implying that the elder farmers were technically more efficient than the younger ones. Apart from other variables, the negative coefficient of extension contact was statistically significant at $1 \%$ level. This explained that the involvement of extension agents tended to increase technical efficiency in soybean production. All variables in the inefficiency model revealed the expected negative sign.

Table 5.6 Parameters of ordinary least square (OLS) and maximum likelihood estimate (MLE) in stochastic frontier production function for all sample soybean farmers in $K_{\text {yaukme }}{ }^{b}$ township

\begin{tabular}{|c|c|c|c|}
\hline \multirow{2}{*}{ Variable } & \multirow{2}{*}{ Parameters } & \multicolumn{2}{|c|}{ Kyaukme } \\
\hline & & OLS & MLE \\
\hline \multicolumn{4}{|l|}{ Stochastic frontier } \\
\hline Constant & $\beta 0$ & $2.120(1.986)$ & $2.838(3.157)$ \\
\hline Seed rate & $\beta 1$ & $0.103(0.767)$ & $0.035(0.309)$ \\
\hline Human labor used & $\beta 2$ & $-0.191(-3.959)^{* *}$ & $-0.209(-5.921)^{* *}$ \\
\hline BSF & $\beta 3$ & $0.003(0.026)$ & $-0.282(-2.711) * *$ \\
\hline Farm size & $\beta 4$ & $-0.248(-2.440)^{* *}$ & $-0.123(-6.533)^{* *}$ \\
\hline Annual income & $\beta 5$ & $0.131(2.299)$ & $0.126(2.448)^{* *}$ \\
\hline Animal labor used & $\beta 6$ & $0.009(0.052)$ & $0.044(0.337)$ \\
\hline Function Coefficient & & -0.193 & -0.409 \\
\hline \multicolumn{4}{|l|}{ Inefficiency Effect } \\
\hline Constant & $\delta 0$ & & $1.508(1.751)$ \\
\hline Household's experience & $\delta 1$ & & $-0.009(-0.104)$ \\
\hline Education level & $\delta 2$ & & $-0.165(-0.727)$ \\
\hline Age of farmer & $\delta 3$ & & $-0.156(-0.607)$ \\
\hline Extension Contact & $\delta 4$ & & $-0.302(-11.057)^{* *}$ \\
\hline \multicolumn{4}{|l|}{ Variance parameter } \\
\hline$\sigma_{\mathrm{s}}^{2}=\sigma_{\mathrm{v}}^{2}+\sigma_{\mu}^{2}$ & $\sigma_{\mathrm{s}}^{2}$ & 0.242 & $0.205(17.221)^{* *}$ \\
\hline$\gamma=\sigma_{\mu}^{2} / \sigma_{\mathrm{s}}^{2}$ & $\gamma$ & 0.480 & $0.999(3154838.0)^{* *}$ \\
\hline Log-likelihood & & -40.029 & -37.86 \\
\hline LR test; one-sided error & & & 4.34 \\
\hline$\chi^{2}(0.05)$ & & & 11.07 \\
\hline Mean technical efficiency & & & 0.49 \\
\hline No. of observations & & 76 & 76 \\
\hline F value & & $4.030 * *$ & \\
\hline $\mathrm{R}^{2}$ & & 0.259 & \\
\hline Critical t value $(\alpha=0.05)$ & & 1.669 & 1.669 \\
\hline Critical t value $(\alpha=0.01)$ & & 2.385 & 2.385 \\
\hline
\end{tabular}

Figures in parenthesis are t values for the corresponding data.

$*$, ** are significant level at $5 \%$ and $1 \%$ respectively.

\subsection{Determinants of output in the stochastic frontier model of the soybean farmers in Taunggyi township}

The OLS and MLE estimates for all sample farmers were presented in Table 5.7. In Table 5.7, the variable associated with seed rate had a positive and significant effect on the yield of soybean at a $1 \%$ level in both OLS and MLE. This implied that an increase in the use of seed by $1 \%$ would lead to an increase in soybean yield by $0.56 \%$. The coefficient of human labor used was positively related to yield but it was not significant. The coefficient of farm size and annual income showed a negative and significant impact on the yield of soybean at a $5 \%$ level. The parameter estimate of annual income was positive and significant at 5\% level in MLE estimation.

In the inefficiency model of Table 5.7, it is noted that the household's experience and the education level harmed inefficiency at a $1 \%$ level of significance, showing that the more experienced and the higher education reduced the inefficiency. Farmers with more education responded immediately to using new technology and to produce closer to frontier output. The estimated coefficient for the age of a farmer in the inefficiency model was positively significant at a $5 \%$ level which indicated that younger farmers were more technically efficient in soybean production than the older ones. Based on these findings, the age of the farmer is not a decisive factor in improving 
the efficiency of farms.

The coefficient of extension contact variable expressed positive and significant at $5 \%$ and $1 \%$ respectively for all farmers. It implied that the provision of extension contact to farmers played a minor role in technology diffusion for soybean production.

The return to scale parameter for the Cobb-Douglas production frontier was estimated by the sum of the elasticity of six input variables for Kyaukme and four input variables for Taunggyi. For all farmers of Kyaukme, the return to scale parameters were (-0.193) in OLS and (-0.409) in MLE. For all sample farmers of Taunggyi, the return to scale parameters were (0.958) in OLS and (0.239) in MLE The elasticity of production is defined as Marginal Physical Product over Average Physical Product (i.e., MPP/APP).

The negative sign of the elasticity was due to the negative value of MPP, which decreases the total output as one unit of variable input increases. Therefore, the sample farmers produced soybean in Region III of the classical production function showing the decreasing return to scale. Region III occurs when excessive quantities of a variable input are combined with the fixed input so much that total output begins to decrease (Doll and Orazem, 1978). The magnitude of the coefficient of overused input was greater than the rest. As a result, the total elasticity became negative. For all farmers group in Taunggyi, their soybean production was in Region II showing the relevant production function of variable inputs. Soybean production in Kyaukme was performed in the Region III of the classical production function with decreasing return to scale due to improper combination of input used. Thus, the function coefficient of Kyaukme township indicated the negative value.

Therefore, the utilization of inputs was irrational and random which causes an improper combination of input used. As a consequence, negative function coefficients were observed. It can be concluded that creating a better market condition is crucially needed for the improvement of soybean yield.

Table 5.7 Parameters of ordinary least square (OLS) and maximum likelihood estimate (MLE) in stochastic frontier production function for all sample soybean farmers in Taunggyi ${ }^{a}$ township

\begin{tabular}{|c|c|c|c|}
\hline \multirow[b]{2}{*}{ Variable } & \multirow{2}{*}{ Parameters } & \multicolumn{2}{|c|}{ Taunggyi } \\
\hline & & OLS & MLE \\
\hline \multicolumn{4}{|l|}{ Stochastic frontier } \\
\hline Constant & $\beta 0$ & $0.197(0.076)$ & $3.458(2.719)$ \\
\hline Seed rate & $\beta 1$ & $0.669(3.525)^{* *}$ & $0.562(2.988)^{* *}$ \\
\hline Human labor used & $\beta 2$ & $0.402(1.431)$ & $0.116(0.487)$ \\
\hline Farm size & $\beta 3$ & $-0.076(-0.538)$ & $-0.280(-2.027)^{*}$ \\
\hline Annual income & $\beta 4$ & $-0.037(-0.450)$ & $-0.159(-2.468)^{*}$ \\
\hline Function Coefficient & & 0.958 & 0.239 \\
\hline \multicolumn{4}{|l|}{ Inefficiency Effect } \\
\hline Constant & $\delta 0$ & & $-1.530(-0.842)$ \\
\hline Household's experience & $\delta 1$ & & $-1.581(-2.994)^{* *}$ \\
\hline Education level & $\delta 2$ & & $-1.404(-3.019)^{* *}$ \\
\hline Age of farmer & $\delta 3$ & & $1.466(1.937)^{*}$ \\
\hline Extension Contact & $\delta 4$ & & $0.794(2.150)^{*}$ \\
\hline \multicolumn{4}{|l|}{ Variance parameter } \\
\hline$\sigma_{\mathrm{s}}^{2}=\sigma_{\mathrm{v}}^{2}+\sigma_{\mu}^{2}$ & $\sigma_{\mathrm{s}}^{2}$ & 0.192 & $0.169(2.842)^{* *}$ \\
\hline$\gamma=\sigma_{\mu}{ }^{2} / \sigma_{\mathrm{s}}{ }^{2}$ & $\gamma$ & 0.050 & $0.478(2.846)^{* *}$ \\
\hline Log-likelihood & & -18.48 & -9.18 \\
\hline LR test; one-sided error & & & $18.60 * *$ \\
\hline$\chi^{2}(0.01)$ & & & 11.34 \\
\hline Mean technical efficiency & & & 0.83 \\
\hline No. of observations & & 32 & 32 \\
\hline F value & & $4.690 * *$ & \\
\hline $\mathrm{R}^{2}$ & & 0.410 & \\
\hline Critical t value $(\alpha=0.05)$ & & 1.703 & 1.703 \\
\hline Critical t value $(\alpha=0.01)$ & & 2.473 & 2.473 \\
\hline
\end{tabular}

Figures in parenthesis are $t$ values for the corresponding data.

$*, * *$ are significant level at $5 \%$ and $1 \%$ respectively.

5.8 Comparison of technical efficiency (TE) in different townships and different income groups

The specific-farm technical efficiency of selected soybean farmers was obtained by using a Cobb-Douglas production function model. The technical efficiency of all farmers widely ranged from 0.21 to 0.99 for Kyaukme Township and from 0.18 to 0.97 for Taunggyi Township. The mean technical efficiency was 0.49 for Kyaukme and 0.83 for Taunggyi. This implied that on average, the farmers were able to obtain about $49 \%$ for Kyaukme and $83 \%$ for Taunggyi of the potential (stochastic) frontier production levels, given the levels of their input technology 
currently being used. The empirical results showed that most of the farmers in Taunggyi had high scores of technical efficiency. However, there was a lower technical efficiency for most farmers in Kyaukme indicating that the soybean farmers in Kyaukme operated quite far to their frontier production function. Thus, in the short run, there is a scope to increase soybean production by $51 \%$ for Kyaukme and by $17 \%$ for Taunggyi by adopting the technology and the techniques used by the best practice in farms.

For all sample farmers in Kyaukme, only $6.6 \%$ of farmers achieved the technical efficiency index of above 0.9. In Taunggyi, the technical efficiency index was an average of 0.83 ranged from 0.18 to 0.97 . Fifty percent of all sample farmers obtained the technical efficiency index above 0.9. The technical efficiency indices for almost all of the farmers were less than one indicating that their soybean productions reached below the production frontier. This finding suggested that the farmers have a chance to be technically efficient to achieve their maximum possible output with a given set of resources. Thus there is a need for encouraging the farmers' ability to exploit the potential in the existing technology.

Table 5.8 Percent distribution of farm-specific technical efficiency of all sample farmers in Kyaukme and Taunggyi

\begin{tabular}{ccccc}
\hline \multirow{2}{*}{ Technical efficiency } & \multicolumn{2}{c}{ Kyaukme } & \multicolumn{2}{c}{ Taunggyi } \\
\cline { 2 - 5 } & frequency & $\mathbf{\%}$ & frequency & \% \\
\hline $0.10-0.19$ & 1 & 1.3 & 1 & 3.12 \\
$0.20-0.29$ & 16 & 21.1 & 0 & 0.00 \\
$0.30-0.39$ & 15 & 19.7 & 1 & 3.12 \\
$0.40-0.49$ & 14 & 18.4 & 1 & 3.12 \\
$0.50-0.59$ & 10 & 13.2 & 1 & 3.13 \\
$0.60-.069$ & 8 & 10.5 & 0 & 0.00 \\
$0.70-0.79$ & 5 & 6.6 & 9 & 9.38 \\
$0.80-0.89$ & 2 & 2.6 & 16 & 28.13 \\
$0.90-1.00$ & 5 & 6.6 & $\mathbf{3 2}$ & 50 \\
\hline Total & $\mathbf{7 6}$ & $\mathbf{1 0 0}$ & $\mathbf{1 0 0}$ \\
\hline
\end{tabular}

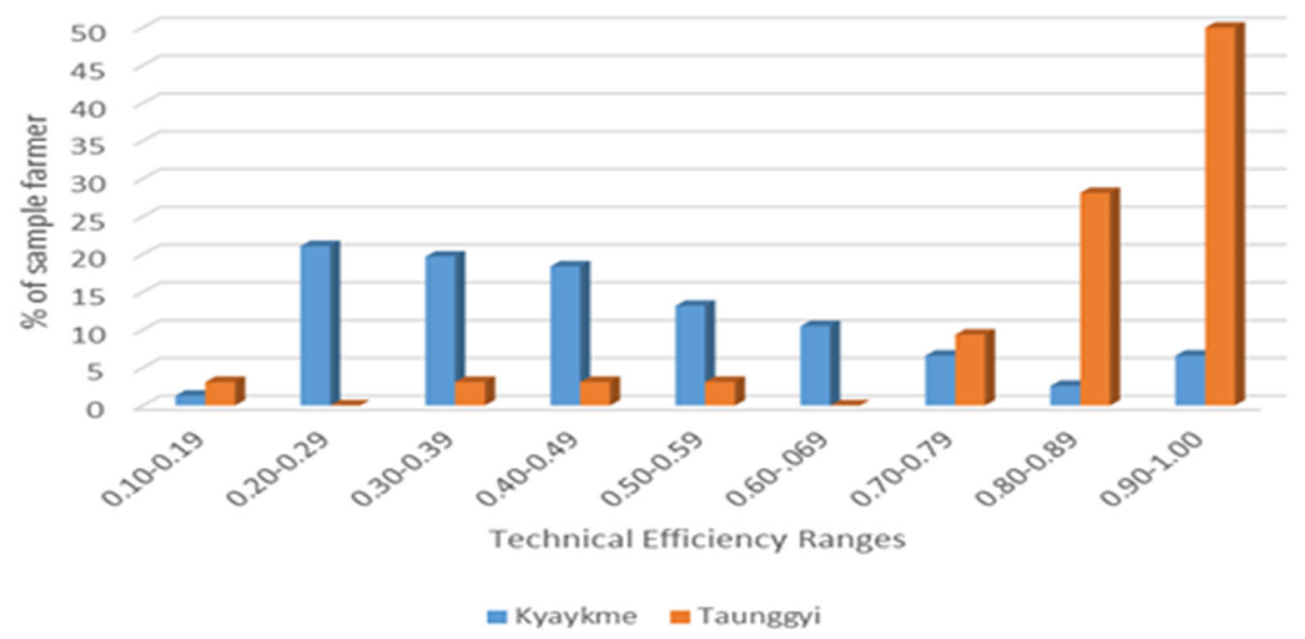

Figure 5. Percent distribution of farm-specific technical efficiency for all sample farmers in Kyaukme and Taunggyi

\section{Conclusion}

This study attempted to measure not only the technical efficiency of sample soybean farmers in different regions but also the farm-specific resource use inefficiency on the production function. The empirical results in comparing the gross margins of the two regions, farmers in Taunggyi earned more than those in Kyaukme. In a comparison of technical efficiency in two regions, farmers in Kyaukme achieved the mean technical efficiency of 0.49 which is lower than in Taunggyi with the average technical efficiency of 0.83 . In the short run, there is a scope for increasing soybean production by $51 \%$ in Kyaukme and by $17 \%$ for Taunggyi through efficient resource use. Therefore an improvement in technical efficiency is still possible under present technology in the study areas. Soybean productivity varies due to differences in production technology and market prices of the crop. In Kyaukme, the lower yield was due to lesser use of fertilizer and limited irrigation which did not reach the recommended amount of water. Besides, more use of human labor in cultivation activities caused the labor-intensive and higher cost of production. Larger farm size had no scale of economies. Since the mean technical efficiency was 0.49 and 
the technical efficiency index lower than 0.80 was for about $90 \%$ of the sample farmers, there are ways and means, by which increased production and efficiency of production can be achieved. In Taunggyi, the lower yield was due to no use of fertilizer, and also larger farm size did not reach scale economies. However, the mean technical efficiency was 0.83 , comparatively higher than in Kyaukme. Therefore, farmers still have an opportunity to increase technical efficiency and to take advantage of the potential in the existing technology.

\section{References}

Aigner, D., C.A.K.Lovell, and P.Schmidt (1977). Formulation and Estimation of Stochastic Frontier Production Function Models. Journal of econometrics. 6. 21-37.

Ali, M. and M. A. Chaudhry (1990). Inter-regional Farm Efficiency in Pakistan's Punjab: A Frontier Production Function Study. Journal of Agricultural Economics. 41(1): 62 - 74

Aung May Than, Kyaw Win, Myint Myint San, and John Ba Maw (2005). Identification of High Yielding Soybean Varieties with High Oil Content Suitable for Specific Regions. Proceedings of the Annual Research Conference held in Yangon on January 7 - 9, 2005 (Agricultural Sciences). MAAFLFS, June 2005. Yangon. The Union of Myanmar.

Aye Aye Khin (2002). Analysis of Technical, Allocative, and Economic Efficiencies of the Selected Sugarcane Farmers at the Three Different Townships in Myanmar. M.Agri.Sc. Thesis. Yezin Agricultural University (YAU), Yezin. Myanmar.

Battesse, G. E and T. J. Coelli (1995). A Model for Technical Inefficiency Effects in a Stochastic Frontier Production Function for Panel Data. Empirical Economics. 20. 325-332.

Blair, R. A. (2007). An Assessment of Agricultural Risk and Diversification on Farming Families' Living Standard under Fuzzy Condition. A Case from Guyana. Farming and Rural System Economics. Edited by Werner Doppler and Siegfried Bauer: volume 90, Margraf Publishers GmbH, 2007, Weikersheim.

Coelli, T. J. (1995). Recent Developments in Frontier Modeling and Efficiency Measurement. Australian Journal of Agricultural Economics, vol.39. No.3 (December 1995). 219 - 245.

Coelli, T. J. (1996). A Guide to FRONTIER Version 4.1: A Computer Program for Stochastic Frontier Production and Cost Function Estimation. Centre for Efficiency and Productivity Analysis (CEPA) Working Papers. Department of Econometrics. University of New England, Armidale, NSW 2351, Australia.

Core, Jim (2005). Agricultural Research Service (ARS) - United States Department of Agriculture (USDA). Agricultural research report. April 2005. Wyndmoor, Pennsylvania.

Doll, J. P., and F. Orazem (1984). Production Economics Theory with Applications. Second edition by John Wiley and Sons, the United States of America.

FAO (1994). Tropical Soybean Improvement and Production. Brazilian Agricultural Research Enterprise, National Soybean Research Center (EMBRAPA-CNPSO), FAO Plant Production and Protection Series. No.27. 1994. Food and Agricultural Organization (FAO) of the United Nations. Rome, Italy.

Farrell, M. J. (1957). The Measurement of Productive Efficiency. Journal of the Royal Statistical Society, A CXX, Part 3, 253 - 290.

IITA (1998). Annual Report. International Institute of Tropical Agriculture. Ibadan. Nigeria.

Khin Htay, Myint Lwin, Aung Shwe and Tin Htut (2002). Effect of Different Biofertilizers on Soybean Production. Journal of Agricultural, Forestry, Livestock and Fishery Sciences. MAAFLFS. August 2002. Yangon. The Union of Myanmar.

Meeusen, W. and J. van den Broeck (1977). Efficiency Estimation from Cobb-Douglas Production Functions with Composed Error. International Economic Review. 18, 435 - 444.

MOAI (2019) Myanmar Agricultural guide 2019. Eurocham Myanmar. Ministry of Agriculture, livestock, and Irrigation (MOALI). Nay Pyi Taw, Myanmar.

Richetti, A. and R. P. Reis (2003). The Soybean Production Frontier and Economic Efficiency in Mato Grosso do Sul, Brazil. Rev. Econ. Social. Rural: vol. 41, no.1. Brasilia Jan./Mar. 2003.

Siregar, M. and Sumaryanto (2003). Estimating Soybean Production Efficiency in Irrigated Area of Brantas River Basin in Indonesia. Indonesian Journal of Agricultural Science. 4 (2). 33 - 39.

Thanda Kyi and M. von Oppen (2001). Stochastic Production Function and Technical Efficiency Estimation: A Case Study on Irrigated Rice Farming in Myanmar, Journal of Myanmar Academy of Agricultural, Forestry, Livestock and Fishery Sciences. March 2001. Yangon, Myanmar.

Theingi Myint (2001). Analysis of Constraints and Technical Efficiency of Irrigated Rice Production System. M.Agri.Sc. Thesis. Yezin Agricultural University, Yezin. Myanmar.

Tun Win (2004). An Economic Assessment on the Farmers' Production Proficiency in Given Input Use: A study of Pre-monsoon Cotton Farmers with Different Income Groups. M.Agr.Sc. Thesis. Yezin Agricultural University, Yezin. Myanmar. 